\title{
Experimental constraints on the evolution of iron and phosphorus-rich melts: experiments in the system $\mathrm{CaO}-\mathrm{MgO}-\mathrm{Fe}_{2} \mathrm{O}_{3}-\mathrm{P}_{2} \mathrm{O}_{5}-\mathrm{SiO}_{2}-\mathrm{H}_{2} \mathrm{O}-\mathrm{CO}_{2}$
}

\author{
Stephan KLEMME \\ Institut für Mineralogie, Universität Münster, Corrensstr. 24, 48149 Münster, Germany
}

\begin{abstract}
Carbonatites occur on most continents and are often associated with economic ore deposits. In rare cases, carbonatites are associated with particular Fe and P-rich rocks, the latter of which can also be of economic importance and can form ores for copper, zirconium, or platinum group elements. Here I present some novel experimental constraints in Fe and $\mathrm{P}$-rich carbonate and silicate-rich systems as a starting point to better understand the origin of these rock types. Phase relations in the system $\mathrm{CaO}-\mathrm{MgO}-\mathrm{Fe}_{2} \mathrm{O}_{3}-\mathrm{P}_{2} \mathrm{O}_{5}-\mathrm{SiO}_{2}-\mathrm{H}_{2} \mathrm{O}-\mathrm{CO}_{2}$ were studied at elevated temperatures $\left(1000-1400{ }^{\circ} \mathrm{C}\right)$ and at high pressures $(1 \mathrm{GPa})$. The liquidus of the systems studied varies between 1300 and $1400{ }^{\circ} \mathrm{C}$. Liquidus phases are, depending on bulk composition, olivine or magnetite. Apatite, pyroxenes and calcite were found to generally crystallize at much lower temperatures. Using experimentally determined mineral and melt compositions, melt compositions were calculated for fractional crystallization of Fe- and P-rich carbonate-rich silicate magma.
\end{abstract}

Keywords: Carbonatite, Fractionation, Phoscorite, System $\mathrm{CaO}-\mathrm{MgO}-\mathrm{Fe}_{2} \mathrm{O}_{3}-\mathrm{P}_{2} \mathrm{O}_{5}-\mathrm{SiO}_{2}-\mathrm{H}_{2} \mathrm{O}-\mathrm{CO}_{2}$

\section{INTRODUCTION}

Carbonatites are magmatic rocks, which occur on most continents. In rare cases, carbonatites may be associated with particular $\mathrm{Fe}$ and $\mathrm{P}-$ rich silicate and carbonate-rich rocks which consist primarily of magnetite, apatite, forsterite-rich olivine, and calcite (Verwoerd, 1967). These rocks were named Phoscorites after the 'Phosphate Development Corporation' and were first described at Phalaborwa, South Africa (Russell et al., 1954). Many phoscorites are of economic importance and are often mined for copper, iron, phosphorus, zirconium, and platinum group elements (Fontana, 2006; Rudashevsky et al., 2004).

Phoscorite deposits are primarily found in alkali complexes on the Kola Peninsula in Russia e.g., (Lee et al., 2006), in the Maymecha-Kotuy Province in Sibiria (Kogarko et al., 1997), in northern Finland (Vartiainen, 1980; Lee et al., 2003; Lee et al., 2005), in Southern Africa (Johnson, 1966; Verwoerd, 1967; von Backström and Jacob, 1979; Eriksson, 1984), as well as in Brazil (Issa Filho et al., 1984; Ribeiro et al., 2005; Fontana, 2006).

In the field, phoscorites are almost always associated

doi:10.2465/jmps.090311

S. Klemme, stephan.klemme@uni-muenster.de with carbonatites which seemed to imply genetic relations between carbonatite and phoscorite (Verwoerd, 1967; Sokolov, 1983; Eriksson, 1984). Genetic models for the origin of phoscorite vary between metasomatic (von Backström and Jacob, 1979), fractional crystallization (von Backström and Jacob, 1979), and liquid immiscibility (Verwoerd, 1967; Lapin and Vartiainen, 1983).

One of the best-studied phoscorite bodies occurs on the Kola Peninsula at Kovdor, Russia. The Kovdor phoscorite ore body is part of a large alkaline ultrabasic intrusion, which was emplaced some $400 \mathrm{Ma}$ ago. The main body of the intrusion consists of turjaites, clinopyroxenites, peridotites, and ijolites. The phoscorite-carbonatite complex forms only a small part of the entire intrusion (Krasnova, 2001; Krasnova et al., 2004). Based on detailed mapping and geochemical analysis, multiple intrusions of phoscorite and carbonatite have been identified (Krasnova and Kopylova, 1988; Krasnova et al., 2004;). The evolution of magmatic phoscorite rocks at Kovdor may be summarized as follows (Krasnova et al., 2004): First intruded phoscorites which were rich in olivine and apatite and contained only small amounts of magnetite. These rocks were followed in succession by magnetiteolivine apatite rocks with only small amounts of calcite. All carbonatite-phoscorites (i.e., $>50 \%$ calcite) were in- 
terpreted to be younger than the main phoscorites and form cross-cutting veins with sharp contacts (Krasnova et al., 2004).

Despite the increasing interest in phoscorite, especially from an economic point of view e.g., (Ribeiro et al., 2005; Rudashevsky et al., 2004), there is no experimental information on the genetic relationships between phoscorites and carbonatites.

In this paper we will not be able to comprehensively unravel the origin of phoscorites, the experiments presented here must be understood as an exploratory study into the phase relations in complex $\mathrm{Fe}^{-}$and $\mathrm{P}$-rich systems. This brings us to the choice of bulk compositions, pressures and temperatures of the experiments. As naturally occurring mineral assemblages of phoscorites vary substantially, it is hard, if not impossible, to precisely estimate bulk composition of naturally occurring phoscorite bodies. Furthermore, it is unclear if phoscorites evolve from carbonatites by fractional crystallisation or if indeed some independent phoscorite parental magma existed (Krasnova et al. 2004).

Matters are further complicated by often very large grain size of naturally occurring phoscorite minerals, i.e. meter-sized apatite crystals and fist sized magnetite single crystals, which further complicates estimation of bulk rock chemistry. However, Krasnova et al. (2004) have developed a rigorous approach to estimate bulk rock chemical composition of Kovdor phoscorites based on careful mapping and bulk rock chemical analysis of a large number of samples.

As a starting point to explore phase relations in $\mathrm{Fe}^{-}$ and $\mathrm{P}$-rich silicate-carbonate system, three different bulk compositions in the system $\mathrm{CaO}-\mathrm{MgO}-\mathrm{Fe}_{2} \mathrm{O}_{3}-\mathrm{P}_{2} \mathrm{O}_{5}-\mathrm{SiO}_{2}-$ $\mathrm{H}_{2} \mathrm{O}-\mathrm{CO}_{2}$ were chosen. It is quite obvious that these three compositions cannot be exhaustive but they are to be seen as a starting point to unravel the magmatic evolution of $\mathrm{Fe}^{-}$and $\mathrm{P}$-rich silicate carbonate magma.

\section{EXPERIMENTAL AND ANALYTICAL TECHNIQUES}

Crystallization experiments were performed at high pressures and high temperatures to simulate fractional crystallization of $\mathrm{Fe}^{-}$and $\mathrm{P}$-rich carbonate-silicate liquids. Three different synthetic bulk compositions (SKHDPH1, SKHDPH2, SKHDPH3) were chosen to investigate phase relations (Table 1). Starting materials consisted of mixtures of oxides $\left(\mathrm{Fe}_{3} \mathrm{O}_{4}, \mathrm{SiO}_{2}\right)$, carbonates $\left(\mathrm{CaCO}_{3}\right)$, phosphates $\left[\mathrm{Ca}_{5}\left(\mathrm{PO}_{4}\right)_{3} \mathrm{OH}\right]$ and hydroxides $\left[\mathrm{Mg}(\mathrm{OH})_{2}\right.$; see Table 1 for details]. The starting material mixtures were ground under acetone in an agate mortar to produce homogeneous mixtures. Starting materials were placed into
Table 1. Starting materials

\begin{tabular}{lccc}
\hline & SKHDPH1 & SKHDPH2 & SKHDPH3 \\
\hline $\mathrm{CaO}$ & 33.1 & 12.7 & 22.3 \\
$\mathrm{MgO}$ & 3.4 & 24.4 & 8.9 \\
$\mathrm{Fe}_{3} \mathrm{O}_{4}$ & 29.6 & 14.0 & 34.9 \\
$\mathrm{P}_{2} \mathrm{O}_{5}$ & 12.5 & 1.1 & 6.3 \\
$\mathrm{SiO}_{2}$ & 6.4 & 28.0 & 16.6 \\
$\mathrm{H}_{2} \mathrm{O}$ & 2.0 & 10.9 & 0.1 \\
$\mathrm{CO}_{2}$ & 13.0 & 8.9 & 10.9 \\
\hline
\end{tabular}

Bulk compositions used in the experiments. Note that SKHDPH1 is modelled after the proposed bulk composition of the Kovdor phoscorite intrusion (Krasnova et al. 2004), whereas SKHDPH2 and SKHDPH3 are estimated bulk compositions to cover a wide range of possible phoscorite bulk compositions.

Fe-saturated platinum metal capsules and welded shut using a conventional arc welder. No attempt was undertaken to control redox states during the runs. However, experimental run products only contained magnetite, no other Fe-oxides or even metallic Fe was observed.

All experiments were conducted at $1.0 \mathrm{GPa}$ in a conventional end-loaded piston cylinder apparatus (Prowatke and Klemme, 2006). The pressure assembly consisted of a graphite heater surrounded by a thin layer of Duran ${ }^{\odot}$ glass (Schott AG, Germany) and a layer of natural talc. This assembly has been pressure calibrated using the fayalite $=$ quartz + ferrosilite (Bohlen et al., 1980) and picrochromite + quartz $=$ enstatite + eskolaite reactions (Klemme and O'Neill, 1997; Klemme and O'Neill, 2000). Experiments were conducted using the piston-in routine: First, a pressure of about $0.25 \mathrm{GPa}$ was applied. Then the sample was heated up to about $550{ }^{\circ} \mathrm{C}$ to soften the glass. During the final compression, pressure and temperature were raised simultaneously. Pressure was kept constant ( $\pm 0.05 \mathrm{GPa}$ ) automatically during the experiments using a screw driven hydraulic system. Temperatures were measured with calibrated $\mathrm{W}_{95} \mathrm{Re}_{5}-\mathrm{W}_{75} \mathrm{Re}_{25}$ thermocouples inserted axially into the assembly using four-bore high-purity $\mathrm{Al}_{2} \mathrm{O}_{3}$ tubing. No correction was made for the dependence of thermocouple emf on pressure. The sample was placed in the hotspot of the assembly, and temperature uncertainties were calibrated to be less than $15^{\circ} \mathrm{C}$.

Experiments were conducted at temperatures between $1000{ }^{\circ} \mathrm{C}$ and $1400{ }^{\circ} \mathrm{C}$ final run temperatures. Initially, however, all experiments were heated to $1400{ }^{\circ} \mathrm{C}$ for $30 \mathrm{~min}$ and were subsequently cooled to the desired final run temperature at a rate of $1 \%$ min. Details of the experimental run conditions (pressures, temperatures, bulk compositions, run durations) are given in Table 2 . The experimental runs were terminated by shutting off electrical power. Typical initial quench rates are in the order of 100 ${ }^{\circ} \mathrm{C} /$ second. Experimental run products were sectioned longitudinally with a miniature diamond saw, and one half 
Table 2. Experimental run conditions and experimental results

\begin{tabular}{ccccll}
\hline Run\# & $\mathrm{T} /{ }^{\circ} \mathrm{C}$ & $\mathrm{P} / \mathrm{GPa}$ & $\mathrm{d} / \mathrm{h}$ & Start mat & Phases present \\
\hline$\# 34$ & 1000 & 1.0 & 69 & SKHDPH1 & Cc (13), Spi (44), Apt (36), Cpx (7) \\
$\# 26$ & 1100 & 1.0 & 36 & SKHDPH1 & Quench (40), Spi (40), Apt (20) \\
$\# 27$ & 1300 & 1.0 & 32 & SKHDPH1 & Quench (51), Spi (29), Apt 20) \\
$\# 33$ & 1400 & 1.0 & 4.7 & SKHDPH1 & Quench (84), Spi (16) \\
$\# 41$ & 1000 & 1.0 & 101 & SKHDPH2 & Spi(29), Cpx(23), Ol(37), Apt(10), F1 \\
$\# 39$ & 1100 & 1.0 & 68 & SKHDPH2 & Spi(29), Cpx(23), O1(37), Apt(10), F1 \\
$\# 40$ & 1200 & 1.0 & 44 & SKHDPH2 & Quench (28), O1 (33), Cpx (20), Spi (19) \\
$\# 50$ & 1300 & 1.0 & 21 & SKHDPH2 & Quench (81), Ol (19) \\
$\# 38$ & 1400 & 1.0 & 1.2 & SKHDPH2 & Quench (100) \\
$\# 82$ & 1000 & 1.0 & 72 & SKHDPH3 & Spi(43), Apt(39), Cc(14), Cpx(4) \\
$\# 81$ & 1100 & 1.0 & 65 & SKHDPH3 & Spi(43), Apt(39), Cc(14), Cpx(4) \\
$\# 76$ & 1250 & 1.0 & 22 & SKHDPH3 & Quench(18), Spi(39), Apt(34) \\
$\# 80$ & 1400 & 1.0 & 4.5 & SKHDPH3 & Quench(76), Spi(24) \\
\hline
\end{tabular}

Temp, temperature in ${ }^{\circ} \mathrm{C}$; P, pressure in $\mathrm{GPa}$; d, run duration in hours; Start mat, starting material; Quench, quenched melt; Fl, fluid; Ol, olivine; Spi, magnetite spinel; Apt, apatite; Cc, calcite; Cpx, clinopyroxene. Phases present: Numbers in brackets refer to modal percent based on mass balance considerations.

Run \# refers to the internal run number.

Table 3. Major element compositions of experimental run products

\begin{tabular}{ccccccccc}
\hline Run No & Phase & $\mathrm{CaO}$ & $\mathrm{MgO}$ & $\mathrm{FeO}^{*}$ & $\mathrm{Fe}_{2} \mathrm{O}_{3}{ }^{*}$ & $\mathrm{SiO}_{2}$ & $\mathrm{P}_{2} \mathrm{O}_{5}$ & Total \\
\hline 80 & Spi & & 12.7 & 16.3 & 69.0 & 0.5 & 0.1 & 98.6 \\
& Quench & 38.8 & 10.0 & 14.5 & & 25.4 & 11.3 & 100 \\
76 & Spi & & 14.5 & 20.1 & 65.0 & 0.1 & & 99.7 \\
& quench & 25.2 & 14.4 & 9.5 & & 50.9 & & 100 \\
& Apt & 56.8 & 0.1 & & & 0.9 & 41.1 & 98.9 \\
40 & Ol & 0.3 & 53.0 & 5.6 & & 41.1 & & 100 \\
& Cpx & 26.8 & 15.9 & 3.0 & & 54.0 & 0.1 & 99.8 \\
& Spi & & 15.0 & 18.0 & 66.0 & 0.4 & & 99.4 \\
50 & Ol & & 51.1 & 8.9 & & 40.1 & 0.1 & 100.2 \\
& Quench & 17.4 & 20.1 & 20.1 & & 40.3 & 2.0 & 100 \\
& Spi & & 2.1 & 29.9 & 67.6 & & & 99.6 \\
& Quench & 53.6 & 3.5 & 14.0 & & 10.8 & 18.1 & 100 \\
& Spi & & 1.3 & 32.0 & 65.2 & & & 98.5 \\
& Apt & 56.1 & & & & 0.8 & 40.9 & 97.8 \\
& Quench & 57.3 & 7.0 & 7.0 & & 26.5 & 2.1 & 100 \\
\hline
\end{tabular}

Representative major element compositions of experimental run products as analysed with electron microprobe.

Quenched liquids were analysed using raster beam scanning techniques.

Phases in other experiments (runs 82, 81, 41,39, and 34) were too small to be analysed. Quench, quenched melt: Ol, olivine; Apt, apatite; Cpx, clinopyroxene; Spi, spinel (magnetite). Quenched melt analyses were normalized to $100 \%$.

* Note that $\mathrm{Fe}$ was measured as total iron and $\mathrm{FeO}$ and $\mathrm{Fe}_{2} \mathrm{O}_{3}$ in spinel analyses was calculated assuming ideal crystal chemistry of spinel

mounted in epoxy and carefully polished with non-hydrous diamond-based polishing pastes. The experimental run products were inspected using optical microscopy and scanning electron microscopy.

Minerals and quench products were analysed for major elements with the electron microprobe (EMP). Polished sections were carbon coated for electron microprobe analysis, using a Cameca SX51 electron microprobe operated using an accelerating voltage of $15 \mathrm{kV}$ and a beam current of $6 \mathrm{nA}$. To minimize element volatility and a "damage" to quench materials under the electron beam an area of several tens of $\mu \mathrm{m}$ was scanned with a $1 \mu \mathrm{m}$ beam. Counting times were $10 \mathrm{~s}$ on peak and $5 \mathrm{~s}$ on background for all elements. The standards used were corundum (Al), periclase $(\mathrm{Mg})$, magnetite $(\mathrm{Fe})$ wollastonite $(\mathrm{Ca}, \mathrm{Si})$, olivine $(\mathrm{Fe}, \mathrm{Mg}, \mathrm{Si})$ and synthetic apatite $(\mathrm{P})$. The raw data were corrected with the 'PAP' software (Pouchou and Pichoir, 1985). In this context, it should be noted that $\mathrm{H}_{2} \mathrm{O}$ and $\mathrm{CO}_{2}$ cannot be analysed with electron microprobe techniques. This has consequences for the analysis of quenched melts as we can only estimate total $\mathrm{H}_{2} \mathrm{O}+\mathrm{CO}_{2}$ concentration based on totals of microprobe analyses but the ratio $\mathrm{H}_{2} \mathrm{O} / \mathrm{CO}_{2}$ cannot be determined with EMP techniques. Additionally, some experimental run products were powdered and analysed with conventional XRD techniques using a Siemens D500 diffractometer. 

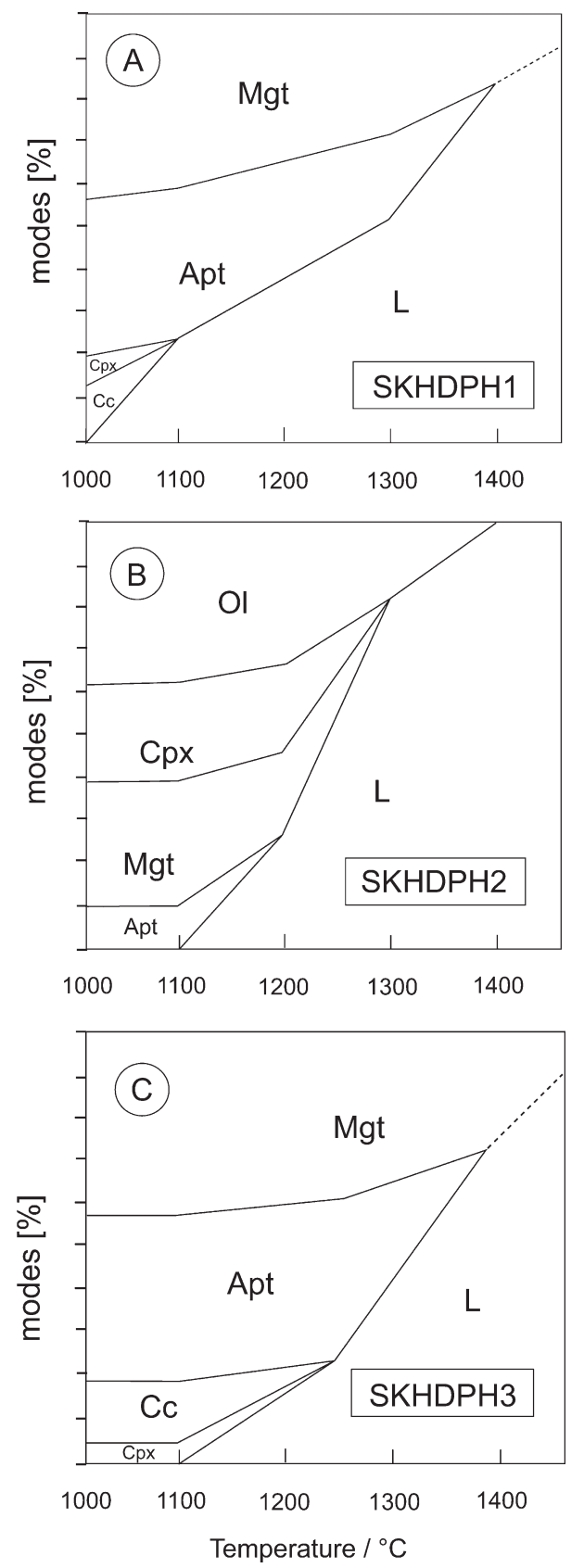

Figure 1. Shown are modal percentages of minerals and melts at different temperatures estimated from back-scattered electron images of experimental run products and mass balance calculations. L, melt; Apt, apatitet; Mgt, magnetite spinelt; Ol, olivinet; $\mathrm{Cpx}$, clinopyroxenet; Cc, calcite. See text for discussion.

\section{RESULTS AND DISCUSSION}

\section{Experimental results}

Experimental results are presented in Tables 2 and 3. The solidus for the three selected bulk compositions was found between $900{ }^{\circ} \mathrm{C}$ and $1000{ }^{\circ} \mathrm{C}$ at $1.0 \mathrm{GPa}$ and the liquidus was found around $1400{ }^{\circ} \mathrm{C}$ or slightly above. The experiments indicate the following crystallization sequence for the selected bulk compositions (Table 2 and Figure 1).

Figure 1 illustrates the crystallization sequence for the three selected bulk compositions. With falling temperatures, SKHDPH1, which is a Fe-rich bulk composition, crystallizes first magnetite, followed by apatite, calcite, and clinopyroxene at lower temperatures. SKHDPH2, which is a bulk composition high in $\mathrm{Mg}$ and $\mathrm{Si}$ with relatively little $\mathrm{P}$ and $\mathrm{Ca}$, first crystallizes olivine, followed by clinopyroxene, magnetite and apatite. SKHDPH2 does not crystallise any significant amounts of calcite even in the lower temperature runs. Large round holes in the experiments at $1000{ }^{\circ} \mathrm{C}$ and $1100{ }^{\circ} \mathrm{C}$ indicate the presence of a free $\mathrm{C}-\mathrm{H}-\mathrm{O}$ fluid phase (Table 1). SKHDPH3, a bulk composition high in $\mathrm{Ca}, \mathrm{Fe}$ and $\mathrm{Si}$, first crystallises magnetite upon cooling, followed by apatite, calcite and clinopyroxene at lower temperatures (Fig. 1). In none of our experiments we observe liquid immiscibility.

Using the experimental results, we can examine the observed sequence of crystallization on Fe-and $\mathrm{P}$-rich magmatic rocks. Depending on bulk composition, magnetite or olivine may be a liquidus phase, followed by crystallization of apatite and calcite at lower temperatures (Fig. 2). Our experiments clearly show that calcite (virtually iron-free) crystallises late from strongly fractionated $\mathrm{Fe}^{-}$and $\mathrm{P}$-rich carbonate-silicate melts. It may, at first sight, seem paradoxical to see more or less pure calcite crystallising from melts in very iron-rich bulk compositions but this is due to the fact that most iron is trivalent and has partitioned into early liquidus spinels, whereas all remaining divalent iron partitions readily into olivine or clinopyroxene rather than into carbonates.

\section{Mineral chemistry}

Table 3 lists mineral and melt compositions. Note that, due to too very small melt pockets, the quenched melt could not be analysed in experiments at lower temperatures. Mineral compositions generally agree rather well with natural spinel, olivine and apatite compositions (e.g., Krasnova et al. 2004). Olivines are $\mathrm{Mg}$-rich with $\mathrm{FeO}$ concentrations of about 5-7 $\mathrm{wt} \%$.

There is no obvious effect of temperature on olivine composition. Apatites and magnetite compositions are also not strongly affected by falling temperature or changing bulk composition. Calcite could only be identified using SEM, but 'clean' analyses with EMP were not possible as the crystals were smaller than $5 \mu \mathrm{m}$. However, semi-quantitative energy dispersive (EDS) scans using a scanning electron microscope (SEM) indicate almost pure calcite with very low $\mathrm{Mg}$ and $\mathrm{Fe}$ concentrations ( $<1 \mathrm{wt} \%$ ). 

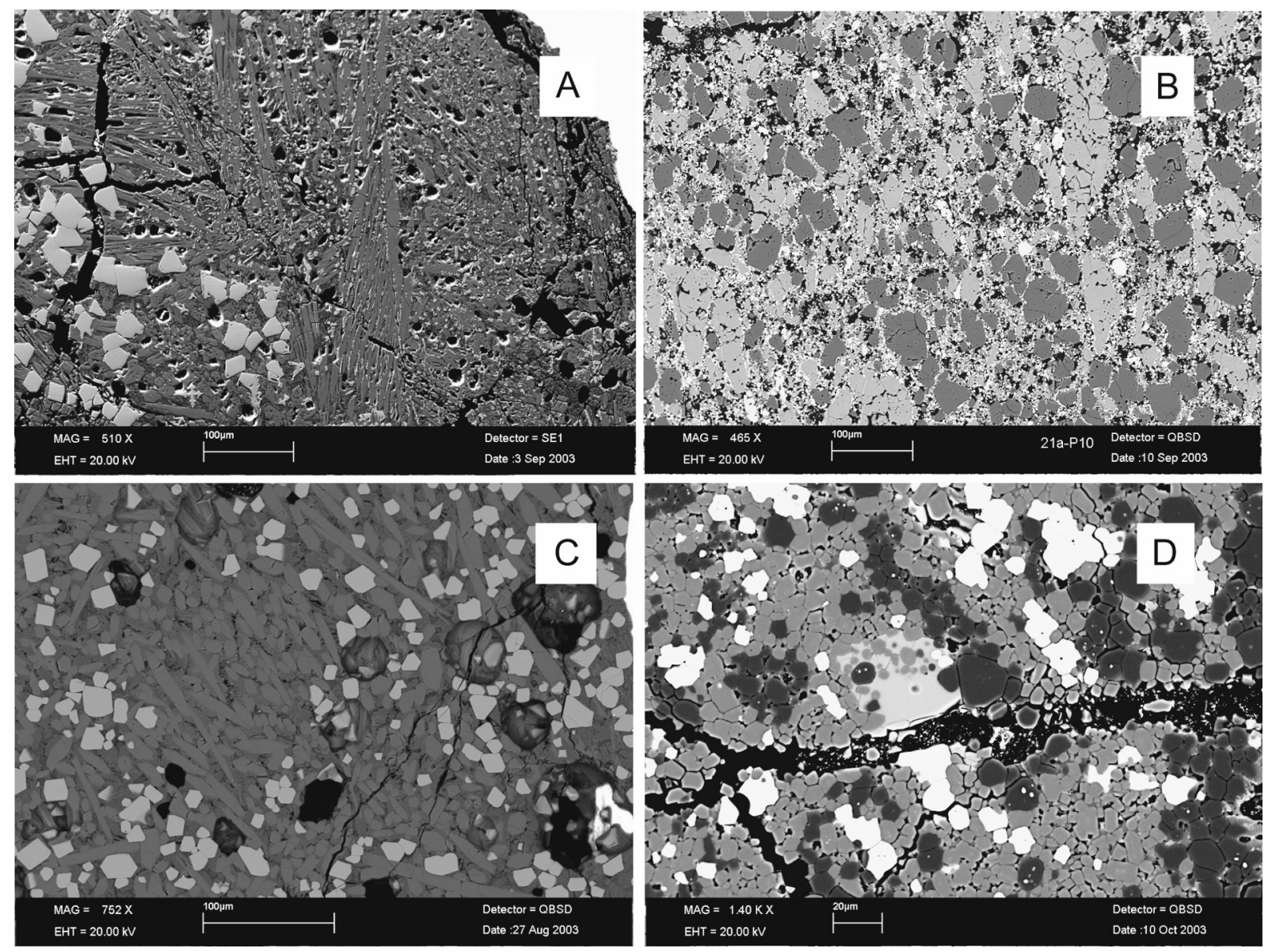

Figure 2. Back-scattered electron images of selected experimental run products. Scale bars as indicated. (A) Run 33: phases present are spinel (grey crystals) and quenched melt. (B) Run 34: subsolidus: phases present are apatite (dark grey), magnetite (white), clinopyroxene, calcite. (C) Run 27: phases present are spinel (very light grey), apatite (darker grey and acicular crystals), and quenched melt. (D) Run 39: phases present are spinel (white), apatite (grey), olivine (dark grey), clinopyroxene (light grey).

\section{Implications for the origin of phoscorites by fractional crystallization?}

The origin of phoscorites remains uncertain. As most phoscorites are associated with carbonatites, fractionation of a carbonatitic parental magma ranges among the most likely hypotheses. The experiments presented here are certainly not sufficient to conclusively argue against liquid immiscibility as mechanism to form phoscorite. However, the experiments may be useful as a starting point to unravel phase relations in a complicated system. The results show clearly that there is no liquid immiscibility in parts of the system $\mathrm{CaO}-\mathrm{MgO}-\mathrm{Fe}_{2} \mathrm{O}_{3}-\mathrm{P}_{2} \mathrm{O}_{5}-\mathrm{SiO}_{2}-\mathrm{H}_{2} \mathrm{O}-$ $\mathrm{CO}_{2}$. This is surprising as phosphorus is known to affect melt structure substantially and liquid immiscibility in phosphorus-rich systems is a well known phenomenon (Rabinovich et al., 1980; Ryerson and Hess, 1980; Mysen, 1998; Suk, 2001) and we can only speculate that this also holds for the parental magmas which crystallized the minerals which make up phoscorites. Clearly, further experi- ments in more carbonate-rich systems are needed to further evaluate the behaviour of iron and phosphorus in fractionating carbonatitic systems.

With the experiments one will not be able to conclusively elucidate the origin of phoscorite. However, the experiments show that fractional crystallization of $\mathrm{Fe}$-and P-rich magma will result in strikingly different melt compositions, mainly driven by the partitioning behaviour of the chemical elements during fractionation. To illustrate this better, melt compositions were calculated from experimentally derived mineral and melt compositions and estimated modal proportions of minerals and melts at different temperatures using mass balance considerations (Fig. 3). Consider, for example, a fractionating melt of SKHDPH1 composition. Upon cooling, SKHDPH1 melts will crystallize magnetite, closely followed by apatite. Crystallisation of magnetite (and apatite) from the system depletes the melt in $\mathrm{Fe}, \mathrm{P}$, and initially also Ca. Consequently, melts will be substantially enriched in silica and $\mathrm{CO}_{2}$. Melts at temperatures below about $1250^{\circ} \mathrm{C}$ contain 

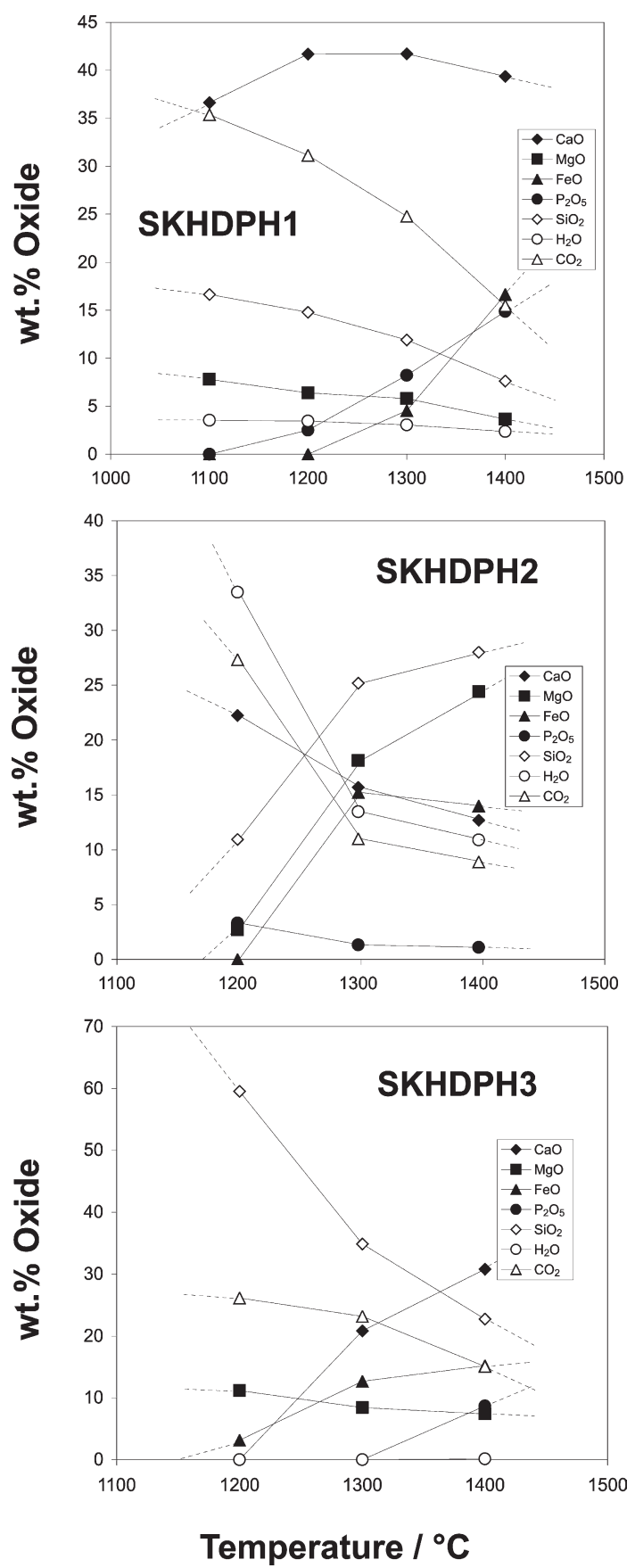

Figure 3. Calculated melt compositions assuming perfect fractional crystallization of phoscorite liquids using mineral and melt compositions (Table 3 ) and estimated modal abundances of minerals and melt at different temperatures (Figure 1).

more than $30 \%$ carbonate component and are very similar to carbonatite melts. This leads to crystallization of calcite and clinopyroxene just before the solidus is reached at temperatures between $1000{ }^{\circ} \mathrm{C}$ and $1100^{\circ} \mathrm{C}$.

Matters are slightly different in SKHDPH2 bulk compositions. Here the initial liquids at $1400{ }^{\circ} \mathrm{C}$, which is above the liquidus of this system, are characterized by high $\mathrm{Mg}, \mathrm{Si}$, and water but relatively low contents of $\mathrm{Ca}$ and Fe. Isobaric cooling of melts in this system results in crystallization of olivine, followed by clinopyroxene, magnetite and apatite with decreasing temperatures. The solidus for this system lies between $1100{ }^{\circ} \mathrm{C}$ and $1200{ }^{\circ} \mathrm{C}$. As forsterite olivine crystallizes between $1400{ }^{\circ} \mathrm{C}$ and $1300{ }^{\circ} \mathrm{C}$, melts are initially depleted in $\mathrm{Mg}$ and $\mathrm{Si}$ and enriched in $\mathrm{Ca}, \mathrm{P}$ and volatiles. Upon further cooling in a fractionating melt, clinopyroxene and magnetite crystallize at temperatures between $1300{ }^{\circ} \mathrm{C}$ and $1200{ }^{\circ} \mathrm{C}$. This leads to a dramatically different melt composition at 1200 ${ }^{\circ} \mathrm{C}$, with low silica, $\mathrm{Mg}$ and very high $\mathrm{H}_{2} \mathrm{O}$ and $\mathrm{CO}_{2}$ concentrations. Melts between $1200{ }^{\circ} \mathrm{C}$ and $1100{ }^{\circ} \mathrm{C}$ are in essence carbonatite melts with normative carbonate contents of more than $50 \%$. Crystallization of apatite at temperatures below $1200{ }^{\circ} \mathrm{C}$ will further deplete the melt in phosphorus and water. However, no carbonates were found in the experiments which were run at subsolidus temperatures at $1100{ }^{\circ} \mathrm{C}$. This does not necessarily exclude the presence of tiny carbonate crystals, which cannot be detected in a complex, extremely fine-grained sample. However, the presence of large holes in the capsules seems to suggest the presence of a fluid phase in the experiments.

Phase relations in SKHDPH3 compositions are slightly different again. At temperatures between $1300{ }^{\circ} \mathrm{C}$ and $1400{ }^{\circ} \mathrm{C}$, magnetite and apatite crystallise. Fractionation of apatite and magnetite depletes the remaining liquid in $\mathrm{Fe}, \mathrm{P}$, and $\mathrm{Ca}$. Consequently, melts under these conditions will be enriched in silica, $\mathrm{CO}_{2}$, and $\mathrm{Mg}$. The enrichment of $\mathrm{CO}_{2}$ in these silicate melts leads to the crystallization of calcite and clinopyroxene before the solidus of this system is approached at temperatures between $1100^{\circ} \mathrm{C}$ and $1200^{\circ} \mathrm{C}$.

It is interesting to note that the solidus in the systems studied here increases systematically as a function of bulk $\mathrm{CO}_{2}$ content between from $1050{ }^{\circ} \mathrm{C}$ at $8.9 \% \mathrm{CO}_{2}$ to 1175 ${ }^{\circ} \mathrm{C}$ at $13 \% \mathrm{CO}_{2}$, in much the same fashion as described by Dasgupta and Hirschmann (2007). The system here, however, is ever so more complicated as our experiments contain much more $\mathrm{Na}, \mathrm{K}, \mathrm{H}_{2} \mathrm{O}$, and $\mathrm{P}$ than the system studied by Dasgupta and Hirschmann (2007) so that it is very difficult to disentangle the different effects of cations on the solidus.

\section{Liquid immiscibility between silicate and carbonate melts}

Previous experimental information on liquid immiscibility in magmatic systems is limited. Efforts have focussed on systems with immiscibility between carbonate and silicate liquids (Hamilton et al., 1979; Wendlandt and Harrison, 
1979; Kjarsgaard and Hamilton, 1988; Kjarsgaard and Peterson, 1991; Lee and Wyllie, 1996; Lee and Wyllie, 1997; Suk, 2001; Suk, 2003;). However, there is little data in $\mathrm{Fe}-$ and $\mathrm{P}$-rich chemical compositions. Moreover, the role of phosphorus on the physical properties of iron-rich silicate liquids and on the silicate-carbonate immiscibility region is uncertain and more data is clearly needed (Suk, 2001). It is well known that phosphorus affects physical properties of silicate melts substantially (Dingwell et al., 1993; Toplis et al., 1994; Toplis and Dingwell, 1996; Mysen, 1998; Mysen and Cody, 2001). Dingwell et al. (1993), for example, report that addition of phosphorus to silicate melts decreases viscosity and the degree of polymerisation of silicate melts. On the other hand, addition of phosphorus to carbonate melts does not seem to affect the immiscibility gap between silicate and carbonate melts (Suk, 2001). However, there is no experimental data on the effect of $\mathrm{Fe}$ on phase relations in phosphate-rich systems and more experimental data in simple systems (e.g., $\mathrm{CaO}-\mathrm{Na}_{2} \mathrm{O}-\mathrm{FeO}-\mathrm{Fe}_{2} \mathrm{O}_{3}-\mathrm{SiO}_{2}-\mathrm{P}_{2} \mathrm{O}_{5}-\mathrm{CO}_{2}$ or similar simple systems) are needed to further our understanding of the possible role of liquid immiscibility between silicate liquids and carbonate liquids.

\section{ACKNOWLEDGMENTS}

I would like to thank both Dr. N.I. Suk and and an anonymous reviewer for two constructive reviews. Dr. S. Prowatke, then at Heidelberg University, is acknowledged for his help with the microprobe measurements. I would also like to thank the Leverhulme trust for support.

\section{REFERENCES}

Bohlen, S.R., Essene, E.J. and Boettcher, A.L. (1980) Reinvestigation and application of olivine-quartz-orthopyroxene barometry. Earth and Planetary Science Letters, 47, 1-10.

Dasgupta, R. and Hirschmann, M.M. (2007). Effect of variable carbonate concentration on the solidus of mantle peridotite. American Mineralogist, 92, 370-379.

Dingwell, D.B., Knoche, R. and Webb, S.L. (1993) The effect of $\mathrm{P}_{2} \mathrm{O}_{5}$ on the viscosity of haplogranitic liquid. European Journal of Mineralogy, 5, 133-140.

Eriksson, S.C. (1984) Age of Carbonatite and Phoscorite Magmatism of the Phalaborwa Complex (South-Africa). Isotope Geoscience, 2, 291-299.

Fontana, J. (2006) Phoscorite-Carbonatite Pipe Complexes: A Promising New Platinum Group Element Target in Brazil. Platinum Metal Reviews, 50, 134-142.

Hamilton, D.L., Freestone, I.C., Dawson, J.B. and Donaldson, C.H. (1979) Origin of carbonatites by liquid immiscibility. Nature, 279, 52-54.

Issa Filho, A., Lima Dos Santos, P.R.A. and Souza, O.M. (1984) Aspects of the geology of the Barreiro Carbonatite Complex, Araxa, MG, Brazil. In Carbonatitic complexes of Brazil:
Geology, Companhia Brasileira de Metalurgia e Mineracao, Sao Paulo, 19-44.

Johnson, R.L. (1966) The Shawa and Dorowa carbonatite complexes, Rhodesia. In Carbonatites (Tuttle, O.F. and Gittins, J. Eds.). Wiley, New York, 205-224.

Kjarsgaard, B.A. and Hamilton, D.L. (1988) Liquid immiscibility and the origin of alkali-poor carbonatites. Mineralogical Magazine, 52, 43-55.

Kjarsgaard, B.A. and Peterson, T. (1991) Nephelinite-carbonatite liquid immiscibility at Shombole volcano, East-Africa - petrographic and experimental evidence. Mineralogy and Petrology, 43, 293-314.

Klemme, S. and O'Neill, H.S. (1997) The reaction $\mathrm{MgCr}_{2} \mathrm{O}_{4}+\mathrm{SiO}_{2}$ $=\mathrm{Cr}_{2} \mathrm{O}_{3}+\mathrm{MgSiO}_{3}$ and the free energy of formation of magnesiochromite $\left(\mathrm{MgCr}_{2} \mathrm{O}_{4}\right)$. Contributions to Mineralogy and Petrology, 130, 59-65.

Klemme, S. and O'Neill, H.S. (2000) The effect of Cr on the solubility of $\mathrm{Al}$ in orthopyroxene: experiments and thermodynamic modelling. Contributions to Mineralogy and Petrology, $140,84-98$.

Kogarko, L.N., Suddaby, P. and Watkins, P. (1997) Geochemical evolution of carbonatite melts in Polar Siberia. Geokhimiya, 143-148.

Krasnova, N.I. (2001) The Kovdor phlogopite deposit, Kola Peninsula, Russia. Canadian Mineralogist, 39, 33-44.

Krasnova, N.I. and Kopylova, L.N. (1988) The geologic basis for mineraltechnological mapping at the Kovdor ore deposit. International Geology Review, 30, 307-319.

Krasnova, N.I., Balaganskaya, E.G. and Garcia, D. (2004) Kovdor - classic phoscorites and carbonatites. In Phoscorite and carbonatites from mantle to mine: The key example of the Kola Alkaline Province (Wall, F.and Zaitsev, A.N. Eds.). Mineralogical Society, London, 99-132.

Lapin, A.V. and Vartiainen, H. (1983) Orbicular and spherulitic carbonatites from Sokli and Vuorijarvi. Lithos, 16, 53-60.

Lee, W.J. and Wyllie, P.J. (1996) Liquid immiscibility in the join $\mathrm{NaAlSi}_{3} \mathrm{O}_{8}-\mathrm{CaCO}_{3}$ to $2.5 \mathrm{GPa}$ and the origin of calciocarbonatite magmas. Journal of Petrology, 37, 1125-1152.

Lee, W.J. and Wyllie, P.J. (1997) Liquid immiscibility between nephelinite and carbonatite from 1.0 to $2.5 \mathrm{GPa}$ compared with mantle melt compositions. Contributions to Mineralogy and Petrology, 127, 1-16.

Lee, M.J., Garcia, D., Moutte, J. and Lee, J.I. (2003) Phlogopite and tetraferriphlogopite from phoscorite and carbonatite associations in the Sokli massif, Northern Finland. Geosciences Journal, 7, 9-20.

Lee, M.J., Lee, J.I. and Moutte, J. (2005) Compositional variation of Fe-Ti oxides from the Sokli complex, north-eastern Finland. Geosciences Journal, 9, 1-13.

Lee, M.J., Lee, J.I., Do Hur, S., Kim, Y., Moutte, J. and Balaganskaya E. (2006) $\mathrm{Sr}-\mathrm{Nd}-\mathrm{Pb}$ isotopic compositions of the Kovdor phoscorite-carbonatite complex, Kola Peninsula, NW Russia. Lithos, 91, 250-261.

Mysen, B.O. (1998) Phosphorus solubility mechanisms in haplogranitic aluminosilicate glass and melt: effect of temperature and aluminum content. Contributions to Mineralogy and Petrology, 133, 38-50.

Mysen, B.O. and Cody, G.D. (2001) Silicate-phosphate interactions in silicate glasses and melts: II. Quantitative, high-temperature structure of P-bearing alkali aluminosilicate melts. Geochimica et Cosmochimica Acta, 65, 2413-2431.

Pouchou, J.L. and Pichoir, F. (1985) "PAP" procedure for im- 
proved quantitative analysis. Microbiology Analysis, 20, 104-105.

Prowatke, S. and Klemme, S. (2006) Trace element partitioning between apatite and silicate melts. Geochimica et Cosmochimica Acta, 70, 4513-4527.

Rabinovich, E.M., Ish-Shalom, M. and Kisilev, A. (1980) Metastable liquid immiscibility and Vycor-type glass in phosphate-silicate systems. Journal of Materials Science, 15, 2027-2038.

Ribeiro, C.C., Brod, J.A., Junqueira-Brod, T.C., Gaspar, J.C. and Petrinovic, I.A. (2005) Mineralogical and field aspects of magma fragmentation deposits in a carbonate-phosphate magma chamber: evidence from the Catalao I complex, Brazil. In 2nd Brazilian Symposium on Volcanism and Related Geologic Settings, Belem, Brazil, 355-369.

Rudashevsky, N.S., Kretser, Y.L., Rudashevsky, V.N. and Sukharzhevskaya, E.S. (2004) A review and comparison of PGE, noble-metal and sulphide mineralization in phoscorites and carbonatites from Kovdor and Phalaborwa. In Phoscorites and Carbonatites from Mantle to Mine: the Key Example of the Kola Peninsula Alkaline Province (Wall, F. and Zaitsev, A.N. Eds.). Mineralogical Society, London, 375-406.

Russell, H.D., Hiemstra, S.A. and Groenevold, D. (1954) The mineralogy and petrology of the carbonatite at Loolekop, Eastern Transvaal. Transactions of the Geological Society of South Africa, 57, 197-208.

Ryerson, F.J. and Hess, P.C. (1980) The role of $\mathrm{P}_{2} \mathrm{O}_{5}$ in silicate melts. Geochimica et Cosmochimica Acta, 44, 611-624.

Sokolov, S.V. (1983) The genetic unity of the apatite-magnetite ores and carbonatites in alkali-ultrabasic intrusions. Geokhimiya $3,438-449$.

Suk, N.I. (2001) Experimental study of liquid immiscibility in silicate-carbonate systems. Petrology, 9, 477-487.
Suk, N.I. (2003) Experimental investigation of carbonate-silicate liquid immiscibility with applications to the formation of barium-strontium carbonatites. Petrology, 11, 400-405.

Toplis, M.J., Dingwell, D.B. and Libourel G. (1994) The Effect of Phosphorus on the Iron Redox Ratio, Viscosity, and Density of an Evolved Ferro-Basalt. Contributions to Mineralogy and Petrology, 117, 293-304.

Toplis, M.J. and Dingwell, D.B. (1996) The variable influence of $\mathrm{P}_{2} \mathrm{O}_{5}$ on the viscosity of melts of differing alkali/aluminium ratio: Implications for the structural role of phosphorus in silicate melts. Geochimica et Cosmochimica Acta, 60, 41074121.

Vartiainen, H. (1980) The petrography, mineralogy and petrochemistry of the Sokli carbonatite massif, northern Finland. Bulletin of the Geolical Survey of Finland, 313, 1-126.

Verwoerd, W.J. (1967) The Carbonatites of South Africa and South West Africa, vol 6. pp. 452, Geological Survey, Pretoria.

von Backström, J.W. and Jacob, R.E. (1979) Uranium in South Africa and South West Africa (Namibia). Philosophical Transactions of the Royal Society of London, A 291, 307319.

Wendlandt, R.F. and Harrison W.J. (1979) Rare-earth partitioning between immiscible carbonate and silicate liquids and $\mathrm{CO}_{2}$ vapor - results and implications for the formation of light rare earth-enriched rocks. Contributions to Mineralogy and Petrology, 69, 409-419.

Manuscript received March 11, 2009

Manuscript accepted June 21, 2009

Published online November 5, 2009

Manuscript handled by Michihiko Nakamura 